\title{
HOUSEHOLD CHARACTERISTICS AND FOREST RESOURCES DEPENDENCE IN THE RUMPI HILLS OF CAMEROON
}

\author{
Mukete, B. $^{1}-$ Sun, Y. ${ }^{*}-$ Etongo, D. $^{2}-$ Ekoungoulou, R. ${ }^{3}-$ Folega, F. $^{4}-$ SAJJAD, S. $^{1}-$ \\ NGOE, M. ${ }^{5}-$ NDIAYE, G. ${ }^{6}$ \\ ${ }^{1}$ State Forestry Administration, Key Laboratory for Forest Resources and Environmental \\ Management, Beijing Forestry University \\ 35 Qinghua East Road, Haidian District, 100083 Beijing, China \\ ${ }^{2}$ National Institute for Regional and Spatial Analysis (NIRSA), Maynooth University \\ Maynooth, W23 F2H6 Ireland \\ ${ }^{3}$ Laboratory of Ecological Planning and Management, Beijing Forestry University \\ 35 Qinghua East Road, Haidian District, 100083 Beijing, China \\ ${ }^{4}$ Laboratoire de Botanique et Ecologie Végétale, Faculté Des Sciences, Université de Lomé \\ BP1515 Lomé, Togo \\ ${ }^{5}$ Department of Agricultural Economics and Management, College of Economics and \\ Management, Nanjing Agricultural University, 1 Weigang, 210095 Nanjing, China \\ ${ }^{6}$ Department of Agricultural Economics and Management, College of Economics and \\ Management, Beijing Forestry University \\ 35 Qinghua East Road, Haidian District, 100083 Beijing, China \\ *Corresponding author \\ e-mail: sunyj@bjfu.edu.cn; phonelfax +86-10-6233-6815 \\ (Received $4^{\text {th }}$ Feb 2018; accepted $2^{\text {nd }}$ May 2018)
}

\begin{abstract}
Rural households have over decades depended on forests and forest products for sustenance and livelihood values. This dependence is usually driven by the individual household's dynamics, forests availability and accessibility. However, with overexploitation and agricultural expansion, these forests are rapidly declining putting in peril household livelihoods. This study aims at examining and analyzing household dynamics and how these dynamics combine with other factors to influence household dependence on forest resources in the Rumpi hills of Cameroon. Data were collected from 484 households, across 20 villages and at four selected sites through household surveys and 20 focus group discussions. Household characteristics such as uneducated heads (p-value 0.000381) significantly influenced the use of forest resources than male heads (P-value 0.000642) and years of residence (11-15) (p-value 0.00624) in the village at the 95\% level of significance. Forest dependence was mostly conditioned by the household's ability to farm, forest abundance, and unemployment. Additionally, income from agriculture and forest resources respectively constituted $36.7 \%$ and $34.1 \%$ of the average total rural household income. Investment in climate-smart agriculture, non-wood domestic cooking energy, agroforestry systems and reliable rural transport systems is necessary in order to curb forest dependence and improve on livelihoods and sustainable forest management initiatives.
\end{abstract}

Keywords: rural livelihoods, household income, forest dependency, sustainable forest management

\section{Introduction}

With a national forest cover estimated at $42 \%$, Cameroon harbours enormous forests and marine resources embedded in a mosaic of landscape structures along basins, plains and mountains. These forests are mostly situated in the south where they make-up the 
western margins of the large tract of the Congo Basin Forests (Robiglio et al., 2010; Ekoungoulou et al., 2018a). However, rural communities live in and around these forests where they depend on several forest resources and products for sustenance and livelihood. Besides serving as sources of wood, farmlands, medicinal plants and hunting grounds, these forests also serve sociocultural and recreational purposes (Etongo and Glover, 2012; Tieguhong et al., 2012; Mukete et al., 2016a).

This dependence which is likely to increase in the coming decades challenges the very existential purposes of these forests often resulting in associated forest degradation, deforestation and constituent biodiversity loss. This stems from the observable depletion of forests due to the combined effects of agricultural expansion, wood harvesting for cooking, heating and wood works (Kimengsi and Lambi, 2015; Mukete et al., 2018b).

Various studies have examined household dependence and the contributions of forest resources to household income and rural livelihoods. For instance, Makoudjou et al. (2017) found forests to contribute on average $38 \%$ of total annual household income. Here, 19, 13 and $6 \%$ of such contributions according to their study came from illegal logging, hunting and harvesting of plant-related non-timber forest products (NTFPs). NTFPs include goods of biological origin other than wood and timber, derived from forests and other land uses such as fallows, woodlots, agroforestry systems, and plantations (Dembner and Perlis, 1999). In the Rumpi hills forest, NTFPs primarily gathered from forests and other land uses include land snails (Archachatina marginata), bush mango (Irvingia gabonensis), bitter cola (Garcinia cola), njansang (Ricinodendron heudelotii), country onion (Afrostyrax lepidophyllus), bush pepper (Piper guineense), and several edible species of mushrooms (Ofundem et al., 2017; Mukete et al., 2018b).

In another study, rural households with better access to forested land such as national parks and forest reserves in Malawi were found to have higher total income, forest income, and relative forest income (Kamanga et al., 2009). Meanwhile, the amount of forest income that households earned was found to vary significantly across study sites in Zambia. This variation was influenced by market and household level factors as well as the occurrence and abundance of forest resources and products (Bwalya, 2013). Accordingly, Belcher et al. (2015) affirmed that, households whose members were relatively more educated are likely to obtain more income from forest related activities than less educated households. Similarly, households made-up mostly of younger members were more dependent on collecting forest products. This is attributed to their starting families and possessing lower agricultural household assets than older and better-established households (McElwee, 2008). On the other hand, households with relatively larger family sizes were found to be more forest resource dependent than those with smaller family sizes (Mamo et al., 2007). Other factors such as geographical location and topographical conditions have also been observed to influence forest resource dependence and use (Zenteno et al., 2013).

Many other studies have linked household forest resource dependence vis-a-vis sustainable forest management initiatives. For instance, Lambi et al. (2012) observed that management and development initiatives that influence households' use of forest resources and forest dependence will invariably affect household employment status and skills through capacity building. Beside household's characteristics, limited opportunities for non-forests livelihood diversification options still prevails, thereby creating a situation of more reliance on forest resources. Such overdependence on forest resource use does not only induce more deforestation and forest degradation, but also 
questions the effectiveness and sustainability of protected area (PAs) initiatives (Ewane et al., 2015).

Sustainable forest management initiatives especially PAs initiatives, can provide significant socioeconomic benefits especially to forest dependent rural communities. Jindal et al. (2012) are of the opinion that, forest management and development initiatives are likely to be compromised should they not tally with household's dynamics and their livelihood activities. Accordingly, Arnold and Perez (2001), Ambrose-Oji (2003), Lambi et al. (2012) and Hajost and Zerbock (2013) observed that, the unabated active participation and interest of local forest dependent rural communities in forest management and development initiatives is closely related to their individual household's characteristics and requirements. Lambi et al. (2012) and Ofoegbu et al. (2017) also found direct links between household characteristics and their decision to carry-out forest related activities. In related studies, factors linked to household conditions were found to influence their motivation and willingness of host communities to participate in forest carbon conservation activities in Mozambique (Jindal et al., 2012), Cameroon (Chia et al., 2013) and Bolivia (Zenteno et al., 2013).

Some studies on sustainable forest management activities have also found that, the long-term sustainability of such initiatives are likely to be efficient if and only if the socioeconomic needs and characteristics of local communities are taken into cognizance. For example, Ambrose-Oji (2003) in her study on the contributions of NTFPs to local livelihoods observed that, forest value could be increased by valorizing the use and importance of NTFPs to local forest dependent rural communities in the Southwest Region of Cameroon. Accordingly, this valorization could then translate into incentives and encourage local villagers to embrace sustainable forest management strategies for the production of livelihood benefits (Ambrose-Oji, 2003). Similarly, Levang et al. (2015) studied the importance of forests concessions to the lives of local forest dependent communities of the east and south regions of Cameroon. Their study found agricultural expansion, unregulated hunting and logging inside the concessions to be setbacks to forest resources utilization for the local communities. They concluded that curtailing these setbacks would necessitate the inclusion of these local communities into stakeholder decision making discussions. Also, Ewane et al. (2015) reported on the importance of a general national reform policy in forest governance and management such as to ensure future sustainable forest management in Cameroon. The study proposed a participatory approach involving both local forest-dependent communities and government institutions which will foster collaboration and adaptive management in forest management. However, tackling the multiple challenges related to forestdependent rural communities and the implications for strategic and practical forest planning has not been carefully done in Cameroon (Lang, 2015; Mukete et al., 2018a). Therefore, additional studies that identify drivers of household forest dependence and the determinants of livelihood patterns for forest-dependent communities are necessary. These would aid in reducing negative impacts on forest resources while ensuring forests are sustainably utilized.

Within the past three decades, the absence of reliable overall quantitative data on household forest resources dependence has preoccupied researchers in Cameroon. In this regard, several studies started addressing different aspects of household forest resources dependence, contributions to household income and rural livelihoods such as: economic contribution to livelihoods (Levang et al., 2015; Makoudjou et al., 2017), poverty alleviation (Ambrose-Oji, 2003; Tieguhong et al., 2012), role of NTFPs (Timko 
et al., 2010; Ofundem et al., 2017), drivers of dependence (Etongo and Glover, 2012; Ewane et al., 2015) and Reducing Emissions from Deforestation and Forest Degradation (REDD+) initiatives (Chia et al., 2013; Awono et al., 2014). These REDD+ initiatives are mechanisms via which developing countries are financially rewarded for achieving carbon emissions reductions and associated with a decrease in the conversion of forests to alternate land uses (Parker et al., 2009; Chia et al., 2013; Awono et al., 2014). Aside financial rewards, reduced deforestation and forest degradation, it facilitates the conservation and enhancement of forest carbon stocks as well as promotes sustainable forest management (Peskett et al., 2008).

Studies that directly address the topic of household characteristics and forest resource dependence in Cameroon are lacking and this is the very first study that addresses the topic in the Rumpi hills of the South West Region of Cameroon. This study bridges that knowledge-gap as it examines household characteristics and forest resource dependence. It also makes an analysis of how household characteristics may influence a household's dependence on forest resource use. This baseline information may help improve macro-level poverty estimates and serve as an input into conservation policy. It may also serve as a knowledge platform for effective collaboration between forest dependent communities, forestry stakeholders and policy makers to design effective community-based forest management and rural development programs aimed at reducing deforestation and forest degradation.

\section{Materials and methods}

\section{Study area}

The Rumpi hills forests $\left(4^{\circ} 49^{\prime} \mathrm{N}^{\circ} 10^{\prime} \mathrm{E}\right)$ and their characteristic horse-shoe shaped Rumpi Hills Forest Reserve, (RHFR) (Latitude: 451'26" Longitude: 9०07'15") are located in Ndian division (Latitude: $4^{\circ} 50^{\prime}$ 00Longitude: $\left.8^{\circ} 50^{\prime} 00^{\prime \prime}\right)$. Ndian division is an administrative unit in the South West Region of Cameroon covering an estimated area of $6626 \mathrm{~km}^{2}$. Its mountainous areas are characterized by undulating Rumpi hills ranging from 400-1800 m with the highest peak at Mount Rata located in the eastern borders of the study area (Fig. 1; SWPA, 2016; Mukete et al., 2018b).

The RHFR is one of the oldest protected areas in Cameroon. Previously known as the Rumpi Hills Native Administration Forest Reserve, it was created in 1941 and occupies an area equivalent to $455 \mathrm{~km}^{2}$ spread across four local council areas in Ndian division. The eastern borders are in Dikome Balue, southern borders in Ekondo Titi, western borders in Mundemba and northern borders in Toko local councils, respectively (Mukete et al., 2018b).

Mangroves and creeks dominated estuary forms a very low and indented point of contact with the sea in the Rio del Rey Estuary along the Gulf of Guinea making-up over $40 \%$ of Ndian. About $25 \%$ of the remaining land area is flat while the other $35 \%$ is mountainous and dominated by the Rumpi hills - our study area. Based on 2001 population survey in addition to future projections, the population of Ndian division is estimated at 362201 of which $17 \%$ are semi-urban and $83 \%$ rural. The average population density is 54.7 inhabitants per $\mathrm{km}^{2}$. This density drops to an estimated 20 inhabitants per $\mathrm{km}^{2}$ in the Rumpi hills and maritime areas. Meanwhile, around the semiurban centers in Ekondo Titi and Mundemba, the population density increases to about 220 inhabitants per km² (BUCREP, 2015; Mukete et al., 2018b). 
Covering over $2300 \mathrm{~km}^{2}$, the Rumpi hills forests constitute a combination of montane, coastal evergreen, drier northern semi-evergreen forests, and other vegetation types (Mukete et al., 2017). These forests are very rich in terrestrial and marine ecological diversity with plant and animal species that range from simple to complex organisms. About 198 bird species including the endangered white-throated mountainbabbler (Kupeornis gilberti) and white-necked pigeon (Columba albinucha) have been identified. Also, many tropical montane mammal, reptile and amphibian species such as the endangered drill (Mandrillus leucophaeus) and forest shrew (Myosorex rumpii) have also been identified (Linder, 2013; Birdlife International, 2014).

The soils are composed of Precambrian clays and sandstones which may have emanated from various volcanic eruptions (Yerima and van Ranst, 2005). The area exhibits two seasons, a dry season from December to February and a rainy season from May to October with annual rainfall ranging from 4027 to $6368 \mathrm{~mm}$. Temperature varies little throughout the year with mean monthly maximum temperatures in the dry season being $31.8{ }^{\circ} \mathrm{C}$ and in the rainy season $18.2{ }^{\circ} \mathrm{C}$. The relative humidity is high during most of the year with minimum monthly values ranging between $78 \%$ and $90 \%$ (Etongo and Glover, 2012; Mukete et al., 2017).

Approximately $90 \%$ of the local population directly or indirectly relies on forests for their livelihood where food and cash crops including yams, spices, vegetables, cocoyams, plantains, cocoa, and oil palm are widely cultivated. The local population especially in the rural areas also depends on the harvesting of NTFPs primarily as an offseason job when pressure on crop cultivation is reduced. In the high altitude forest areas of Dikome Balue and Toko local councils, hunting and NTFPs gathering are important activities for the local communities. The rural population also benefits from employment as labourers provided by the agroindustrial giant Pamol Plantations Plc, smallholder plantations and in small private businesses. The national road N16 from Kumba in Meme division passes through the major semi-urban areas of Ekondo Titi and Mundemba in the southern and western zones (Fig. 1). Moreso, the different maritime ports of the Rio del Rey estuary also provide excellent access points by water to neighbouring Nigeria, Equatorial Guinea and Gabon which facilitates the evacuation of forest resources (Malleson, 2000; Mukete et al., 2018b).

\section{Sampling of rural communities}

Data on the drivers of household characteristics and forest resources dependence were obtained through different methods. They include household surveys - semistructured, close and open-ended recall questions, and 20 focus group discussions (FGDs) with household heads and forestry stakeholders (Mukete et al., 2017). Majority of the studied villages are adjacent to the RHFR and are among those that had existed and had been using the forest even before the horse shoe-shaped RHFR was created. These villages thus represent an important source for historical data. The number of households in each village was obtained from the local village chiefs because official census data are lacking. In villages with less than 25 households, only semi-structured and open ended questionnaires through a door to door survey were used. Meanwhile, villages with more than 25 households were divided into groups for easy implementation of FGDs. The number of participants in a FGD was limited to 10 and included volunteers and or randomly selected farmers of at least 18 years old (as required by Cameroon Law). Their National Identity Cards were verified and in cases where this was unavailable, recommendation was sought from the local village chief or 
his representative. In instances where potential participants were unable to effectively communicate in English language, "Pidgin English" or Oroko dialect was used by the first author to ensure proper understanding. The interview captured at least $70 \%$ of the households per village giving a total of 484 interviews of households across the 20 adjacent villages.

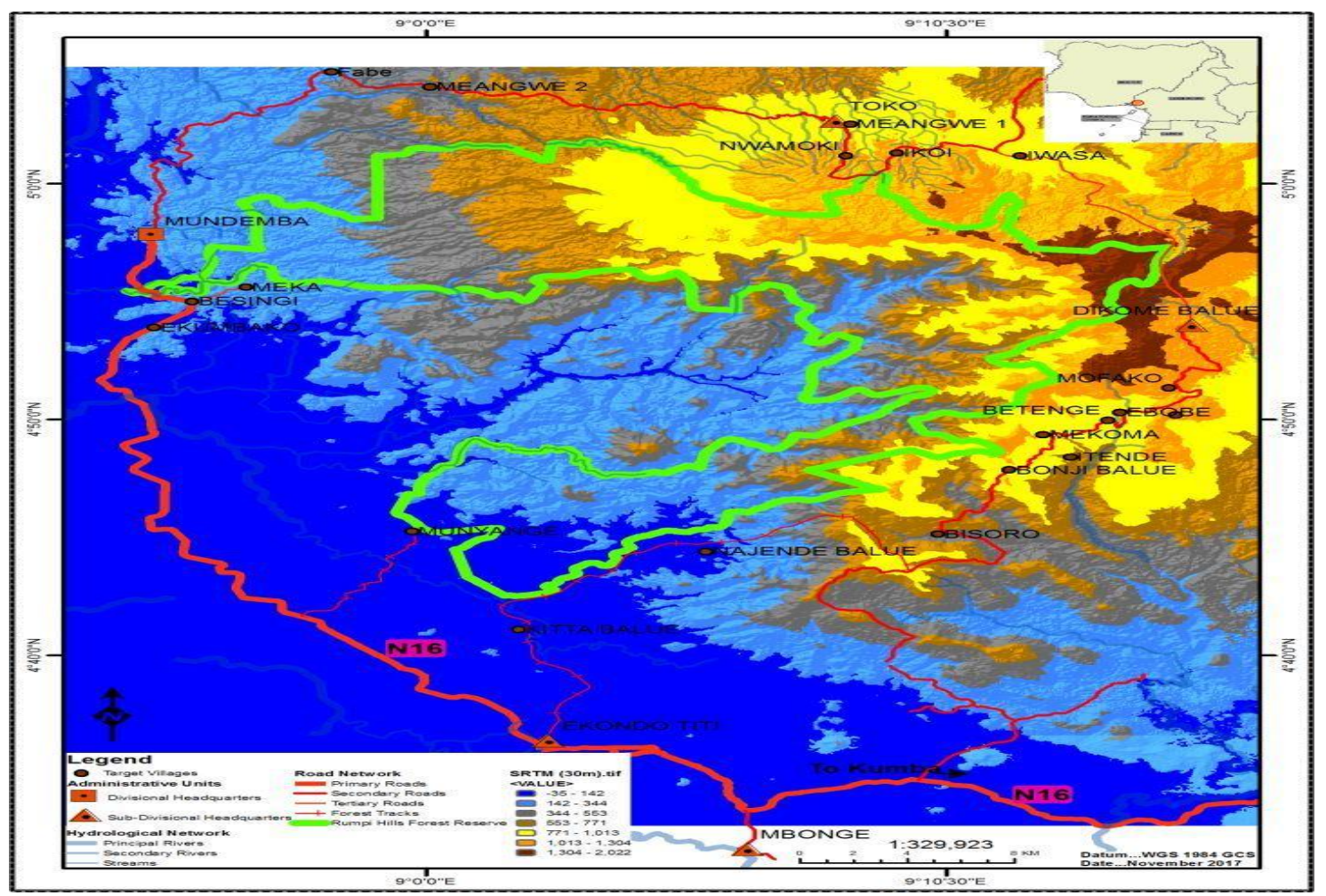

Figure 1. Location map of the study area

The household which was the basic unit for this research was defined as a group of people living together in the same house who regularly cook and eat from the same pot. Here, questions were centered on the gender, age, annual income, income sources, educational level, marital status, ethnicity; farming practices and off-farm activities of the household head. Information was also collected from local forestry stakeholders on the drivers of deforestation at the micro level, their engagement of rural households in mitigating the effects of deforestation in addition to the implementation of forest management policies. The questionnaires were designed so as to gain an understanding of household characteristics, the driving causes of their dependence on forests and its implications for forest sustainability. A two-point type scale (Yes $=$ important, No $=$ not important) was used to examine the importance of forests to household income, sustenance, livelihood and access into protected areas (Ofoegbu et al., 2017).

\section{Statistical analyses}

Data collected through the questionnaire-based survey were analyzed using Stata 13.0 for Mac. A regression analysis was also conducted to determine the relationship between the dependent and independent variables. Hence, the dependent variables were regressed on independent variables in order to determine if there was a statistically 
significant relationship and how much variation of the dependent variables was explained by the independent variables. The $\mathrm{p}$-value $\leq 0.05$ represented statistical significance at the $95 \%$ confidence interval and the data analysis procedure used in this paper was adopted from Kleinbaum et al. (1998) and Mbatu (2006).

The econometric model is expressed as follows (Eq.1):

$$
Y=\beta_{0}+\beta_{1} X_{1}+\beta_{2} X_{2}+\beta_{3} X_{3}+?+\beta_{n} X_{n}+E
$$

where $\mathrm{Y}$ is the dependent variable and represents household forest dependence. The eight variables examined in this study and used as dependent variables are included in Table 1.

Meanwhile, $X_{n}$ are the independent variables which represent the potential causes or human forces that influence the variability of dependent variables. These are the household characteristics that affect forest dependence or 20 explanatory variables that have been classified in Table 1 .

$\beta_{o}$ is a constant or intercept and it represents the change in the dependent variable when there is no change in the independent variables.

$\beta_{\mathrm{n}}$ are the regression coefficients and represent the percentage change in the dependent variable when the independent variables increase by $1 \%$.

$\mathrm{E}$ is the error term or error component. It represents the variations of the dependent variable that are not explained by the independent variables included in the model.

Table 1. Variables used in the econometric model

\begin{tabular}{c|c}
\hline Dependent variables $(\mathbf{Y})$ & Independent variables $\left(\mathbf{X}_{\mathbf{n}}\right)$ \\
\hline Little or no financial cost to use forests & Gender of household heads: male and female \\
\hline Forest resource abundance & $\begin{array}{c}\text { Age of household heads: 0-21 years, 22-60 years, over 60 } \\
\text { years old }\end{array}$ \\
\hline Easy access to forest & $\begin{array}{c}\text { Residence period in village: 0-5 years, 6-10 years, 11-15 } \\
\text { years, 16-20 years, and over 20 years }\end{array}$ \\
\hline Absence of alternative energy & $\begin{array}{c}\text { Educational level of household heads: university, secondary, } \\
\text { primary, and uneducated }\end{array}$ \\
\hline Unemployment & Residential status of household heads: indigenous and migrant \\
\hline Shock avoidance & $\begin{array}{c}\text { Marital status of household heads: married, single, divorced, } \\
\text { and widowed }\end{array}$ \\
\hline Farming ability & \\
\hline Animal rearing ability &
\end{tabular}

\section{Results}

\section{Age and gender characteristics of the household}

Out of the 484 households (164 in Dikome Balue, 96 in Ekondo Titi, 119 in Mundemba and 105 in Toko, respectively), 57\% were male-headed while $43 \%$ were female-headed, most of whom were either widows or divorced and were in the 21-40 age group. Besides Ekondo Titi - a hotspot for immigrants from other parts of the country, the respondents especially in the villages have lived there for more than 20 years. Therefore, the period of residence in the villages was greater than one year and majority of the respondents were indigenous and also married. For household age 
composition, $18.8 \%$ belonged to the $0-21$ years age group, $39.6 \%$ in the $21-40$ years (very active age group), $25.6 \%$ in the 41-60 years (active group) and 16\% in the $61+$ years age (retirement or inactive) age group. Additionally, a minuscule $2.3 \%$ respondents had acquired university education, $20.4 \%$ had secondary education while $37.3 \%$ had completed primary education. Therefore, an average of $40 \%$ respondents across the case study villages had no formal education and could neither read nor write. This lack of formal education does not qualify them for formal jobs either with the government or private sector but were actively involved in agriculture and other extractive activities (Table 2).

Table 2. Demographic and socioeconomic characteristics of the household heads across the four study sites. Here, 57\% were male-headed while $43 \%$ were female-headed, and where $39.6 \%$ were in the 21-40 years (very active age group)

\begin{tabular}{|c|c|c|c|c|c|}
\hline $\begin{array}{l}\text { Demographic } \\
\text { characteristics }\end{array}$ & Dikome Balue \% & Ekondo Titi \% & Mundemba \% & Toko \% & $\begin{array}{l}\text { Total }(\%) \text { of } \\
\text { respondents }\end{array}$ \\
\hline $\begin{array}{l}\text { Household head } \\
\text { males }\end{array}$ & 54.2 & 67.7 & 53.8 & 52.4 & 57 \\
\hline $\begin{array}{l}\text { Household head } \\
\text { females }\end{array}$ & 45.8 & 32.3 & 46.2 & 47.6 & 43 \\
\hline $\begin{array}{l}\text { Age of household } \\
\text { head: } 0-21\end{array}$ & 20.1 & 13.5 & 15.9 & 25.7 & 18.8 \\
\hline $21-40$ & 41.6 & 40.6 & 39.3 & 37.1 & 39.6 \\
\hline $41-60$ & 24.3 & 27.1 & 26.2 & 24.8 & 25.6 \\
\hline $61+$ & 14 & 18.8 & 18.6 & 12.4 & 16 \\
\hline Period of residence: & & & & & \\
\hline $0-5$ & 17.1 & 17.7 & 18.5 & 14.2 & 16.9 \\
\hline $6-10$ & 12.2 & 12.5 & 6.7 & 12.4 & 11 \\
\hline $11-15$ & 15.2 & 26 & 9.2 & 10.5 & 15.2 \\
\hline $16-20$ & 12.2 & 23 & 13.4 & 10.5 & 14.7 \\
\hline$>20$ & 37.2 & 20.8 & 52.2 & 52.4 & 42.2 \\
\hline $\begin{array}{l}\text { Educational level: } \\
\text { university }\end{array}$ & 3.1 & 6.2 & 0 & 0 & 2.3 \\
\hline Secondary school & 20.7 & 16.7 & 24.3 & 20 & 20.4 \\
\hline Primary & 31.1 & 30.2 & 53.7 & 34.3 & 37.3 \\
\hline No education & 45.1 & 46.9 & 21.8 & 45.7 & 40 \\
\hline Indigenous & 75.6 & 77.1 & 82.4 & 73.3 & 77.1 \\
\hline Migrant & 24.4 & 22.9 & 17.6 & 26.7 & 22.9 \\
\hline Marital status: single & 24.4 & 21.9 & 28.6 & 15.2 & 22.5 \\
\hline Married & 56.7 & 66.7 & 59.6 & 62 & 61.2 \\
\hline Divorced & 12.2 & 8.3 & 10.1 & 9.5 & 10 \\
\hline Widowed & 6.7 & 3.1 & 4.2 & 13.3 & 6.3 \\
\hline Cash crop farming & 90 & 93 & 91 & 66 & 85 \\
\hline Food crop farming & 97 & 94 & 100 & 100 & 98 \\
\hline Animal rearing & 44 & 86 & 55 & 71 & 64 \\
\hline NTFPs harvesting & 32 & 88 & 35 & 63 & 54.5 \\
\hline Hunting & 14 & 35 & 12 & 34 & 23.7 \\
\hline Petty business & 20 & 39.5 & 51 & 14 & 31.1 \\
\hline Fishing & 7.5 & 5 & 7 & 6 & 6.4 \\
\hline Public transport & 7 & 14 & 9 & 12 & 10.5 \\
\hline Wood extraction & 100 & 100 & 100 & 100 & 100 \\
\hline Others & 5 & 4 & 2 & 1 & 3 \\
\hline
\end{tabular}




\section{Occupation, income sources and levels}

Households are mainly involved in cash and food crop cultivation with the latter mainly practiced through shifting cultivation and agroforestry systems. Farm sizes were instrumental in the choice of practice engaged by farm households because those having 0.2 to 2.5 hectares (ha) of land mostly cultivated both food and limited amount of cash crops in the so-called agroforestry systems. Meanwhile, cash crop cultivation primarily occurred on farmlands ranging between 2.5 and 10 ha. In agroforestry systems, cash crops (cocoa, oil palm), fruits trees (mango, African plum and oranges) and food crops (cassava, maize, and yams) are intercropped or farmed together.

Aside farming, domestic animals have been part of the culture, tradition and lifestyle of the local populations for as long as they have existed. Many of the households (64\%) domesticate animals like fowls, goats, pigs and dogs. This culture, tradition and lifestyle is also embedded in household environmental resources consumption and marketing of forest products including wood, rattan and bamboo products, fruits and nuts; hunting and fishing products such as rodents, birds, snails, tilapia, mudfish and shrimps.

Off-farm income mainly from petty businesses was reported by $31.1 \%$ of the surveyed households. In addition, fewer numbers of households corresponding to $3 \%$ also earned income from rendering services such as transportation. Other additional income sources particularly during the farming season include shared labour in the form of hire, meeting groups and two-party. Two party is a practice whereby at harvest time, the crops are shared with the land owner on the basis of usually a verbal agreement (Mukete et al., 2017). Similarly, households derived $65.9 \%$ of their average total household income from farming and animal rearing. Meanwhile, forest products including fuelwood collection and wood harvesting were also important livelihood and household income sources contributing over $34.1 \%$ of household income.

From Table 3, fruits and nuts include banana, mango, oil palm, plantain, cashew, plum; spices are mostly bush pepper, grains of paradise, ginger; vegetables are pepper, okra, tomato, egusi, garden eggs; root crops refer to tubers such as yams, cocoyams, cassava, and potatoes; cereals comprise simply of corn while others include cocoa, tea, coffee, rubber and sugar cane.

Table 3. Percentage contribution of farming, animal rearing and forest resources harvesting to household income

\begin{tabular}{|c|c|c|c|c|c|}
\hline $\begin{array}{c}\text { Farming } \\
\text { income source }\end{array}$ & $\begin{array}{c}\text { Percentage }(\%) \\
\text { contribution }\end{array}$ & $\begin{array}{l}\text { Animal } \\
\text { income } \\
\text { source }\end{array}$ & $\begin{array}{l}\text { Percentage }(\%) \\
\text { contribution }\end{array}$ & $\begin{array}{c}\text { Forest income } \\
\text { source }\end{array}$ & $\begin{array}{c}\text { Percentage }(\%) \\
\text { contribution }\end{array}$ \\
\hline Fruits/nuts & 10.6 & Fowls & 22.5 & Medicine & 13.2 \\
\hline Spices & 11.2 & Goats & 13.4 & $\begin{array}{c}\text { Wood } \\
\text { harvesting }\end{array}$ & 23.9 \\
\hline Vegetables & 19.4 & Dogs & 8.2 & $\begin{array}{l}\text { Bamboo } \\
\text { products }\end{array}$ & 13.8 \\
\hline Root crops & 25.8 & Sheep & 5.3 & Fuelwood & 28.3 \\
\hline Cereals & 22.4 & Ducks & 2.1 & $\begin{array}{l}\text { Rattan } \\
\text { products }\end{array}$ & 11.1 \\
\hline Others & 10.6 & $\begin{array}{l}\text { Cats } \\
\text { Snails } \\
\text { Pigs } \\
\text { Others }\end{array}$ & $\begin{array}{c}7.1 \\
20.7 \\
5.6 \\
15.1\end{array}$ & Others & 9.7 \\
\hline $\begin{array}{l}\text { Total percentage } \\
(\%) \text { contribution }\end{array}$ & 36.7 & & 29.2 & & 34.1 \\
\hline
\end{tabular}


Aside domestic animals, others include hunted animals such as rodents, birds, monkeys, antelopes, and deer. Meanwhile, forest products include wood harvested for construction, chewing stick, woodwork and charcoal production; bamboo products include mats, bags, thatches, and fishing tools; rattan products include baskets, chairs. Others include ropes, gum, fish, njangsang, bush onion, bush mango.

\section{Drivers of household forest resources dependence}

Results indicated that agricultural skill is the most important driver of household forest dependence as reported by $91 \%$ of the surveyed households (Table 4). Other drivers that influenced forest dependence as mentioned by respondents included easy access to forests in a village, little or no financial cost to use forests, forest abundance, absence of alternative energy sources and unemployment. Statistical analysis also found these drivers to be statistically significant $(\mathrm{P}$-value $=0.000)$ at the $95 \%$ confidence interval although differently across the study area.

Table 4. Reasons for household forest resources dependence in the study area. Here, agricultural skills or ability to farm was the most important factor responsible for household forest dependence

\begin{tabular}{|c|c|c|c|c|c|c|}
\hline \multirow{2}{*}{$\begin{array}{c}\text { Socioeconomic } \\
\text { drivers }\end{array}$} & \multirow{2}{*}{ Response } & \multicolumn{4}{|c|}{ Number of household heads in subdivision (\%) } & \multirow{2}{*}{$\begin{array}{c}\text { Total } \\
\text { response \% }\end{array}$} \\
\hline & & Dikome Balue & Ekondo Titi & Mundemba & Toko & \\
\hline $\begin{array}{l}\text { Little or no } \\
\text { financial cost to } \\
\text { use forests }\end{array}$ & $\begin{array}{l}\text { Yes } \\
\text { No }\end{array}$ & $\begin{array}{l}86 \\
14\end{array}$ & $\begin{array}{l}77.6 \\
22.4\end{array}$ & $\begin{array}{l}67 \\
33\end{array}$ & $\begin{array}{l}82.6 \\
14.4\end{array}$ & $\begin{array}{l}78.3 \\
21.7\end{array}$ \\
\hline Forest abundance & $\begin{array}{l}\text { Yes } \\
\text { No }\end{array}$ & $\begin{array}{l}78.2 \\
21.8\end{array}$ & $\begin{array}{l}69.3 \\
30.7\end{array}$ & $\begin{array}{l}45.9 \\
54.1\end{array}$ & $\begin{array}{l}78.8 \\
21.2\end{array}$ & $\begin{array}{l}68 \\
32\end{array}$ \\
\hline $\begin{array}{l}\text { Easy access to } \\
\text { forest }\end{array}$ & $\begin{array}{l}\text { Yes } \\
\text { No }\end{array}$ & $\begin{array}{c}92.1 \\
7.9\end{array}$ & $\begin{array}{l}68.5 \\
31.5\end{array}$ & $\begin{array}{l}61.2 \\
38.8\end{array}$ & $\begin{array}{c}96.4 \\
3.6\end{array}$ & $\begin{array}{l}79.5 \\
20.5\end{array}$ \\
\hline $\begin{array}{l}\text { Absence of } \\
\text { alternative energy }\end{array}$ & $\begin{array}{l}\text { Yes } \\
\text { No }\end{array}$ & $\begin{array}{l}81.7 \\
18.3\end{array}$ & $\begin{array}{l}57.8 \\
42.2\end{array}$ & $\begin{array}{l}49.3 \\
51.7\end{array}$ & $\begin{array}{l}88.9 \\
11.1\end{array}$ & $\begin{array}{l}69.4 \\
30.6\end{array}$ \\
\hline Unemployment & $\begin{array}{l}\text { Yes } \\
\text { No }\end{array}$ & $\begin{array}{l}73.7 \\
26.3\end{array}$ & $\begin{array}{l}48.1 \\
51.9\end{array}$ & $\begin{array}{l}78.6 \\
21.4\end{array}$ & $\begin{array}{l}84.8 \\
15.2\end{array}$ & $\begin{array}{l}71.3 \\
28.7\end{array}$ \\
\hline Shock avoidance & $\begin{array}{l}\text { Yes } \\
\text { No }\end{array}$ & $\begin{array}{l}82.4 \\
15.6\end{array}$ & $\begin{array}{l}44.3 \\
55.7\end{array}$ & $\begin{array}{l}49 \\
51\end{array}$ & $\begin{array}{l}88.3 \\
11.7\end{array}$ & $\begin{array}{l}66 \\
34\end{array}$ \\
\hline Agricultural skills & $\begin{array}{l}\text { Yes } \\
\text { No }\end{array}$ & $\begin{array}{c}93.9 \\
6.1\end{array}$ & $\begin{array}{c}95.5 \\
4.5\end{array}$ & $\begin{array}{c}91.2 \\
8.8\end{array}$ & $\begin{array}{l}83 \\
17\end{array}$ & $\begin{array}{c}90.9 \\
9.1\end{array}$ \\
\hline $\begin{array}{l}\text { Animal rearing } \\
\text { skills }\end{array}$ & $\begin{array}{l}\text { Yes } \\
\text { No }\end{array}$ & $\begin{array}{l}44.7 \\
55.3\end{array}$ & $\begin{array}{l}86 \\
14\end{array}$ & $\begin{array}{l}55.6 \\
45.4\end{array}$ & $\begin{array}{l}71.2 \\
28.8\end{array}$ & $\begin{array}{l}64.3 \\
35.7\end{array}$ \\
\hline
\end{tabular}

Results of the statistical analysis are presented in Table 5 while causal relationships between drivers of household forest resources dependence and household characteristics are presented in Table 6. Each model represents the relationship between a dependent variable and the two independent variables with most significant affects. For instance, easy access to forest resources correlated significantly $(\mathrm{P}<0.01)$ with male household heads and also with uneducated household heads (Table 6). Furthermore, forest abundance was statistically significant $(\mathrm{P}<0.05)$ and correlated significantly with household heads that were over 60 years of age and have acquired just primary education. Similarly, the desire to avoid shocks as a result of poor harvest and job loss 
was significant $(\mathrm{P}<0.01)$ and related positively with household heads whose status was single and divorced (Table 6).

The people that have lived in study areas for 6 to 10 years and who were also married were the two variables that significantly affected the dependent variable, little or no financial cost to use forests (Eq. 2). Here, a $1 \%$ increase for households that have lived for 6 to 10 years in the communities, the lower their cost of using forest resources by $3.02 \%$. Therefore, forest dependence is expected to increase especially if majority of the surveyed households have lived in the area for 6 to 10 years. Meanwhile, a 1\% increase for household heads that were married would decrease forest dependence by $0.92 \%$ although the impact is not statistically significant.

$$
\text { Cost }=102+3 * R_{-} 610-0.9 * \text { Married }
$$

Similarly, the two variables - household heads that were over 60 years old and with just primary education have significant impacts on forest resources abundance as expressed in Equation 3. Hence, a 1\% increase in this age group and education level decreases household dependence on forests by $2.11 \%$ and $1 \%$ respectively. Therefore, as the number of elders and children increases, forest dependence decreases.

$$
\text { Abundance }=139.4-2.1 * \text { Age_60 }-1 * \text { Primary }
$$

Easy access to forests is significantly affected by the number of male household heads and people with no education. Contrary to conventional thinking that maleheaded households are likely to have more access to forest resources, results indicated that a $1 \%$ increase in male headed households also decreases their easy access to forests by $1.93 \%$ and by implication their dependence (Eq. $4 a$ and Table 6 ). On the other hand, a $1 \%$ increase among uneducated household heads resulted to a $1.36 \%$ increase in their easy access to forest resources. It shows therefore that, local communities are likely to become more forest-dependent as illiteracy rate increases given that all other factors are held constant (Eq. $4 b$ and Table 6).

$$
\begin{aligned}
& \text { Access }=135.3-1.9 * M_{-} \text {heads }+1.3 * \text { Uneducated } \\
& \text { Access }=-57.5+1.9 * F_{-} \text {heads }+1.3 * \text { Uneducated }
\end{aligned}
$$

Furthermore, a $1 \%$ increase for household heads that were over 60 years of age resulted to a $6.27 \%$ decrease on the lack of alternative sources of energy. For household heads that have lived in their respective communities for 11 to 16 years, an increase of $1 \%$ also increases their lack of alternative energy sources by $0.58 \%$. This implies that, as the number of household's increases especially for those that have resided in the area for 11 to 16 years and those who also lack alternative energy sources beside the use of wood energy, their dependence on forests will also increase (Eq. 5).

$$
\text { Alternative energy }=160.6-6.2 * \text { Age_60 }+0.5 * R \_115
$$

Based on Equation 6 and Table 6, a 1\% increase for households who have resided in the respective communities for a period of 6 to 10 years increases forest dependence 
especially for those that were unemployed by $199.3 \%$. It is observed here that, a $1 \%$ increase among uneducated household heads also decreases unemployment by $47.26 \%$.

$$
\text { Unemployment }=-226.2+199.2 * R_{-} 610-47.2 * \text { Uneducated }
$$

Accordingly, Equation 7 represents the relationship between the number of people that depended on forests in order to avoid shocks based on two marital status - single and divorced. Results showed that a $1 \%$ increase for those that were single decreases their shock avoidance by $4.3 \%$ or people who are single are less forest-dependent. Additionally, a $1 \%$ increase for divorced households would cause shock avoidance to increase by $12.52 \%$, hence forest dependence is likely to increase as the number of divorced households increases.

$$
\text { Shock avoidance }=34.7-4.3 * \text { Single }+12.5 * \text { Divorced }
$$

In Equation 8, the number of people with farming ability was regressed at two levels: households who lived in the study area for 16 to 20 years and who were also married. It was observed that an increase by $1 \%$ for households, who have lived in the villages for 16 to 20 years, also increased their farming activities by $1.58 \%$. Therefore, as the number of households who have lived in these communities for 16 to 20 years increases, forest dependence will also increase as a result of farming activities. This is because households search for new farmlands in the forests when the productivity of their current fields shows signs of decrease. On the other hand, a $1 \%$ increase for household heads that were married also decreases farming activities by $1.54 \%$.

$$
\text { Farming ability }=162.1+1.5 * R_{-} 1620-1.5 * \text { Married }
$$

The number of people with animal rearing ability was modeled against the number of people aged 21 years at most and who were also married. Regression results showed that a $1 \%$ increase in household heads that are married would cause animal rearing to increase by $4.46 \%$. Therefore, a $1 \%$ increase for household heads that were at most 21 years of age increases animal rearing by $0.5 \%$. Thus, forest dependence also increases as the number of young people increases and as more people get married (Eq. 9).

$$
\text { Animal rearing }=-218.2+0.5 * \text { Age_021 }+4.46 * \text { Married }
$$

Table 5. Regression analysis on the drivers of household forest resources dependence and where farming ability was the most important driver of household forest dependence

\begin{tabular}{c|c|c|c|c}
\hline Variable & Mean & Standard deviation & Minimum & Maximum \\
\hline Little or no financial cost to use & 78.3 & 8.285731 & 67 & 86 \\
forests & 68.05 & 15.39231 & 45.9 & 78.8 \\
Forest abundance & 79.55 & 17.32291 & 61.2 & 96.4 \\
Easy access to forest & 69.425 & 18.88657 & 49.3 & 88.9 \\
Absence of alternative energy & 71.3 & 16.11976 & 48.1 & 84.8 \\
Unemployment & 66 & 22.55467 & 44.3 & 88.3 \\
Shock avoidance & 90.9 & 5.557577 & 83 & 95.5 \\
Farming & 64.375 & 18.05849 & 44.7 & 86 \\
Animal rearing & &
\end{tabular}


Table 6. Regression results on socioeconomic variables that explained drivers of household forest dependence. Results of the statistical analysis are presented in Tables 5 and 6 with causal relationships between drivers of household forest resources dependence and household characteristics

\begin{tabular}{|c|c|c|c|c|}
\hline Variables & \begin{tabular}{|c|} 
(1) \\
Little or no financial \\
cost to use forests
\end{tabular} & (2) & $\begin{array}{c}\text { (3) } \\
\text { Easy access }\end{array}$ & $\begin{array}{c}\text { (4) } \\
\text { No alternatives }\end{array}$ \\
\hline $\begin{array}{c}\text { Res6to10 } \\
\text { (Years of residence, 6- } \\
10 \text { years) }\end{array}$ & $3.020 * *$ & - & - & - \\
\hline- & $(0.162)$ & - & - & - \\
\hline $\begin{array}{c}\text { Married } \\
\text { (Married household } \\
\text { heads) }\end{array}$ & $-0.927 *$ & - & - & - \\
\hline- & $(0.108)$ & - & - & - \\
\hline $\begin{array}{c}\text { AgeOver60 } \\
\text { (Household heads over } \\
60 \text { years) }\end{array}$ & - & $-2.114 * *$ & - & $-6.273 * * *$ \\
\hline- & - & $(0.0651)$ & - & $(0.0147)$ \\
\hline $\begin{array}{c}\text { Primary } \\
\text { (Household heads with } \\
\text { primary education) }\end{array}$ & - & $-1.009 * *$ & - & - \\
\hline- & - & $(0.0191)$ & - & - \\
\hline $\begin{array}{c}\text { MHeads } \\
\text { (Male household } \\
\text { heads) }\end{array}$ & - & - & $-1.930 * * *$ & - \\
\hline- & - & - & $(0.000642)$ & - \\
\hline $\begin{array}{c}\text { Uneducated } \\
\text { (Household heads with } \\
\text { no education) }\end{array}$ & - & - & $1.360 * * *$ & - \\
\hline- & - & - & $(0.000381)$ & - \\
\hline $\begin{array}{c}\text { Res11to15 } \\
\text { (Years of residence, } \\
11-15 \text { years) }\end{array}$ & - & - & - & $0.582 * * *$ \\
\hline- & - & - & - & $(0.00624)$ \\
\hline Constant & $102.0 * *$ & $139.4 * * *$ & $135.4 * * *$ & $160.6^{* * * *}$ \\
\hline- & (6.347) & $(0.991)$ & $(0.0345)$ & $(0.215)$ \\
\hline Observations & 4 & 4 & 4 & 4 \\
\hline R-squared & 0.997 & 1.000 & 1.000 & 1.000 \\
\hline Variables & $\begin{array}{c}(5) \\
\text { Unemployment }\end{array}$ & \begin{tabular}{|c|}
$(6)$ \\
Shock avoidance
\end{tabular} & $\begin{array}{c}(7) \\
\text { Farming }\end{array}$ & $\begin{array}{c}(8) \\
\text { Animal rearing }\end{array}$ \\
\hline $\begin{array}{c}\text { Res6to10 } \\
\text { (Years of residence, 6- } \\
\text { 10years) }\end{array}$ & $199.3 * * *$ & - & - & - \\
\hline- & $(2.265)$ & - & - & - \\
\hline $\begin{array}{c}\text { Uneducated } \\
\text { (Household heads with } \\
\text { no education) }\end{array}$ & $-47.26 * * *$ & - & - & - \\
\hline- & $(0.532)$ & - & - & - \\
\hline
\end{tabular}




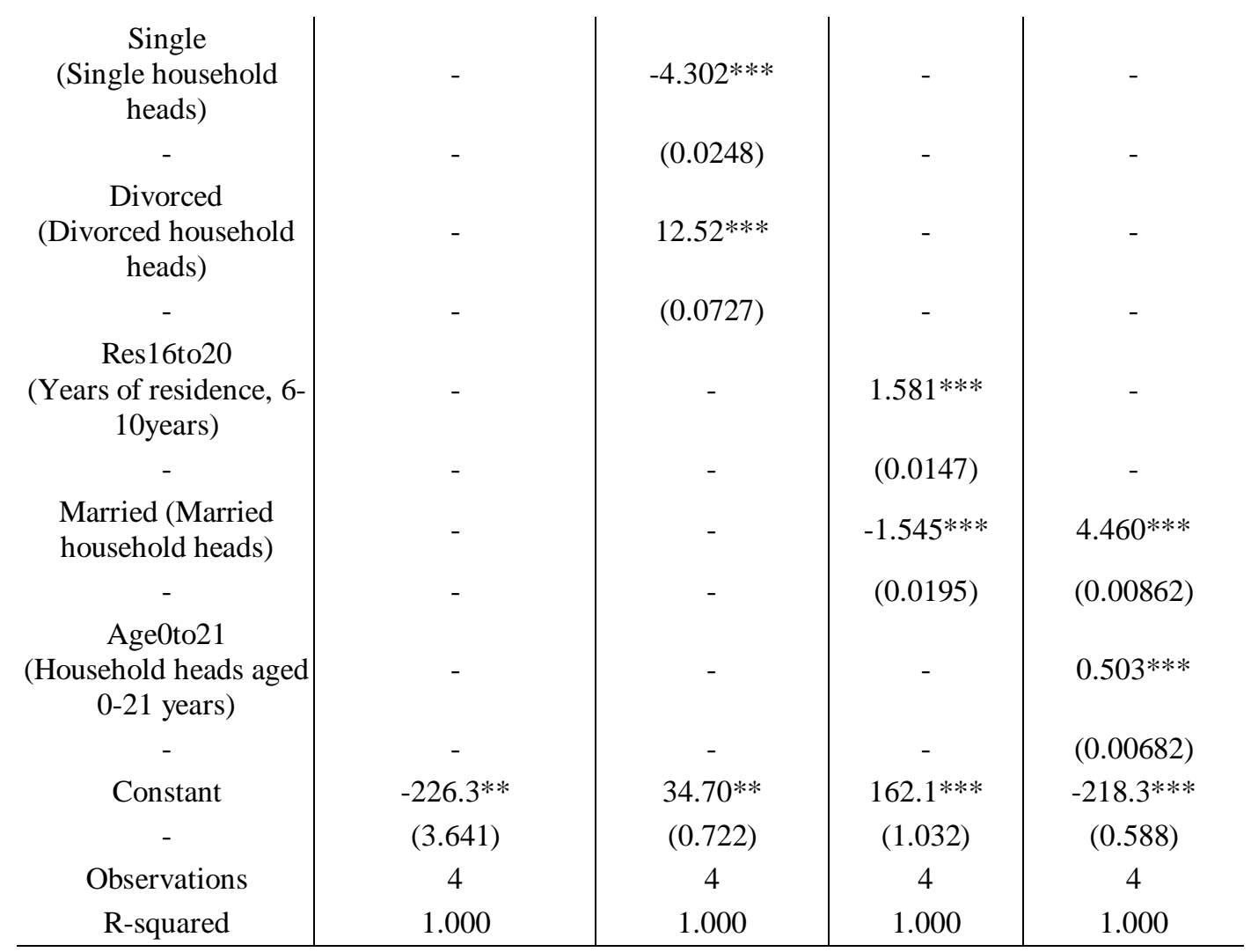

Standard errors in parentheses $* * * \mathrm{p}<0.01, * * \mathrm{p}<0.05, * \mathrm{p}<0.1$

\section{Discussion}

\section{Household characteristics and forest resource dependence}

Households' forest dependence was found to be significantly influenced by characteristics such as gender and the level of education of household heads, age, marital status, and years of residence in the village. As the number of uneducated household heads increases, forest dependence due to easy access to forest resources also increases. This implies that, rural households become more forest-dependent as the illiteracy rate increases. Farm households primarily lack the basic education that could enable them gain any type of formal employment. As such, these households largely depend on agriculture (food and case crop cultivation) and other extractive activities such as the harvesting of NTFPs from the forest and other land uses. Even when farmers are aware of other options for livelihood diversification, translating such knowledge into practice is confronted with socio-cultural, economic, institutional and even environmental constraints. Therefore, with constraints on rural households that depend primarily on land and forests, their dependence on forests resources is a more feasible option to augment household income and improve on livelihoods (Etongo et al., 2015; Mukete et al., 2018b).

Additionally, households' forest dependence due to minimal or no financial costs associated to the use of forest resources was mostly determined by the number of household heads who had lived in the villages for 6 to 10 years and also among those that were married. Therefore, as the number of households who have lived in these villages for 6 to 10 years increased, forest dependence also increased. This is due to the 
absence of other options for livelihood such as in the industrial sector unavailable in most towns of Cameroon. Similarly, household forest dependence as a result of forest resources abundance was determined by the quota of household heads that were over 60 years old with primary education as their highest qualification. Hence, an increase in the number of elderly people and children decreased forest dependence. This may be related to the fact that both groups of people do not have the physical capabilities required for exploiting forest resources especially across a roughed terrain such as the Rumpi hills.

Also, household forest dependence as a result of no alternative source of household domestic energy beside wood energy was observed to be driven by the number of respondents above 60 years and those who had lived in these villages for 11 to 16 years. Just as in the little or no financial cost in the use of forest resources, forest dependence decreased as the people get older. Given the youthful population in the study area, dependence on forest resources is a common process because harvesting of forest products requires not only lots of energy but in most case longer distances have to be cover in the forests - conditions that are likely to be fulfilled by the younger and energetic youthful male population. Therefore, as the male population grow older; their ability to harvest forest resources decreases often due to lack of physical strength and in some cases poor health conditions.

In addition, forest dependence in order to avoid shocks correlated with the number of people who were single and also those that were divorced. This infers that singles are less likely to use forest resources because they have less responsibility in the form of the number of mouths to be fed. On the other hand, forest dependence increased as the number of divorced cases increased. In this case, divorced people may still have mouths to feed and were more likely to avoid shocks (poor crop harvests and job loss) through the use of forest resources for household subsistence.

From another perspective, forest dependence due to subsistent activities such as animal rearing increased as more people got married. Most of the household heads that were married with relatively younger families had low capital and labour inputs. For majority of such households, forest dependence is greatest as nearby bushes and forests are cleared for cropping and harvesting of fodder for livestock. The relatively younger families also bear the brunt of early child-bearing years and face the greatest pressures to increase forest dependence in order to augment their limited labour force which likely insufficient to allow the household to self-sufficient on food crop cultivation (Murphy et al., 1999; Mukete et al., 2018b).

According to Malleson (2000), households that are involved in animal rearing and who have also lived long in the villages are likely to be more forest depended. This is due to the relatively low cost associated with supporting their livelihood strategies. Therefore, forest resources, their availability, access and abundance around rural communities generally favour animal rearing as a livelihood strategy. Related studies Bwalya (2013), Tieguhong et al. (2012) and Angelsen et al. (2014) observed that income and the rate of consumption of forest products by a household were more likely to increase its demand for forest-related livelihood activities.

\section{Economic drivers and household forest resources dependence}

Generally, there is a high dependency on forest and farm related income sources which are a reflection of low household annual income, an overview of the differences in income levels and a lack of access to credit schemes as well as government subsidies 
(Mukete et al., 2018a). Estimates on poverty based on the United Nations global poverty index correspond to people living on less than 1.25 USD (United State Dollars) or 625 FCFA (Central African Franc) a day and where majority are located in developing countries particularly in rural areas (Phimmachanh et al., 2015). From these various estimates, $49.2 \%$ of the households were found to be poor and belong to the lowest income group of less than 460 USD per annum. This explains the high dependency on forest and agriculture related activities in order for these households to meet their daily livelihood requirements. Also, rural households have not fully engaged off-farm sources of income and a minuscule or in most cases, a complete absence of the industrial sector additionally explain their high dependency on forest and agriculture related activities (Mukete et al., 2016b). Meanwhile, household daily income was estimated in the local currency, the Franc CFA at 1 USD $=500$ FCFA (Etongo and Glover, 2012).

From another perspective, the high dependency on the harvesting of forest resources, food and cash crop cultivation, and hunting portrays a higher price advantage with respect to the other income sources at both village and distant markets. These have provided strong incentives for agricultural and forest resource extraction. Additionally, majority of households lack access to credit schemes and government subsidies. As such, they primarily depend on family circles, friends and farmers' groups for loans. This lack of access to finance has also been a driving force for agricultural and forest resource dependence in the Rumpi hills (Malleson, 2000; Mukete et al., 2017). This is also because poverty limits the household's ability to invest in agriculture at a larger scale, thus local household agricultural investments continue to remain at the subsistence level.

Similar studies by Babulo et al. (2009) and Angelsen et al. (2014) found a relationship between household income and resource dependency. These studies observed that low income households were more dependent on natural resources leading to ecological degradation. Meanwhile Kamanga (2009) and Nguyen et al. (2015) observed a high variability in the relationship between poverty and ecological degradation. Narain et al. (2008) and Bwalya (2013) on the other hand found middle income households to be less dependent on forest resource as compared to the poorest and relatively richer households. Also Zenteno et al. (2013) used social ecological systems theory (SES) to analyze change in forest communities in the northern Bolivian Amazon. Their study observed that despite the various changes in both internal and external policies, population growth, competition among households and more profitable economic opportunities still threaten forest resources dependence. Garekae et al. (2017) studied the level of household forest dependency using a range of socioeconomic factors around the Chobe Forest Reserve of Botswana. Their study found age and education to significantly influence household forest resource dependence. Their study also showed forest dependence to decrease with increasing respondent age and educational level. Therefore, the youth were likely to be more forest dependent when compared to the elderly age group with higher levels of educational attainment who are likely to be less forest dependent.

\section{Conclusion}

It is necessary to integrate household dynamics and surrounding forest conditions in forest related studies especially in remote forest depended communities. This is because 
household reliance on forest resources is conditioned by various household characteristics and forest outcomes - structure, composition and abundance. As such forest dependence by households can be comprehensively evaluated through the lens of household and farm characteristics, access to forests and forest incomes.

Household characteristics such as gender and education of household heads, age, marital status, and years of residence in the village influence household's dependence on forest resources. Aside from household characteristics, other factors particularly related to surrounding forest conditions such as easy access to forests in a village, minimal or no financial costs on the use of forests and forest abundance are likely to influence a household's dependence on forest resources. These household characteristics when considered in isolation did not usually influence forest resources dependence except when considered in combination with surrounding forest conditions. For instance, as the number of uneducated household heads increases, forest dependence due to easy access to forest resources increases. This implies that, rural households become more forest-dependent as the illiteracy rate increases ceteris paribus. Formal education and the level of attainment especially higher education are important not just for formal employment but can position farm households to effectively engage in agriculture in a sustainable way with little reliance on NTFPs collection. But this is not the case in the rural areas in Cameroon and the Rumpi hills in particular as majority of the farm households are uneducated. The capacity building that is to be provided by the agricultural extension workers also run short of staff and contacts with farmers are minimal and not available in most cases.

Meanwhile, household characteristics such as the number of people above 60 years and those who have lived for 11 to 16 years in their villages influenced household forest dependence as a result of the lack of alternative source of energy beside fuelwood. Therefore, forest dependence decreased as the people get older and given the youthful population in the study area, dependence on forest resources is forecasted to increase in the coming decade except a transition from wood to more renewable energy sources becomes evident. Meanwhile, a household's forest dependence is also influenced by its desire to avoid shocks and this is conditioned by household characteristics such as the number of single and divorced households in the village. This implies that singles are less likely to use forest resources because they have less responsibility in the form of the number of mouths to feed.

This study also observed that a household's dependence on forest resources portrays a higher price advantage with respect to the other income sources at both village and distant markets. These have provided strong incentives for agricultural and forest resource extraction because majority of households lack access to credit schemes and government subsidies, but depend primarily on family circles, friends and farmers groups for loans. This lack of access to finance which in turn limits a households' ability for livelihood diversification has also been a driving force for agricultural and forest resource dependence in the Rumpi hills.

The study also corroborates existing scientific literatures that forest resources dependence at the household level is usually conditioned by household characteristics, surrounding forest conditions and prevailing household economic dynamics. It has also brought forward an understanding of the major factors that influence household forest resources dependence especially in remote communities. Some of these factors include household characteristics (gender, educational level, marital status, and age of household heads); surrounding forest conditions (forest resource abundance and easy 
access to forest) and economic dynamics (absence of alternative energy, shock avoidance, unemployment, income sources and levels as well as the ability to farm and rear animals). Using these factors, effective policies can be developed that take into cognizance socioeconomic needs and characteristics of forest dependent communities. These policies will also include a broad-based assessment of local community socioeconomic conditions before the development, implementation and monitoring of forest management and exploitation initiatives.

Acknowledgements. This study was financed by the World Wildlife Fund and Russel Train Fellowship for Nature (WWF/EFN) Grant No. ST60

Conflict of interests. The authors declare that there is no conflict of interests regarding this paper.

\section{REFERENCES}

[1] Ambrose-Oji, B. (2003): The contribution of NTFPs to the livelihoods of the 'forest poor': evidence from the tropical forest zone of south-west Cameroon. - International Forestry Review 5(2): 106-117.

[2] Angelsen, A., Jagger, P., Babigumir, R. et al. (2014): Environmental income and rural livelihoods: a global comparative analysis. - World Development 64(Supplement 1): S12-S28.

[3] Arnold, M., Perez, R. (2001): Can non-timber forest products match tropical forest conservation and development objectives? - Ecological Economics 39(3): 437-447.

[4] Awono, A., Somorin, A., Eba'a Atyi, R., Levang, P. (2014): Tenure and participation in local REDD+ projects: insights from southern Cameroon. - Environment Science Policy 35: 76-86.

[5] Babulo, B., Muys, B., Nega, F., Tollens, E., Nyssen, J., Deckers, J., Mathijs, E. (2009): The economic contribution of forest resource use to rural livelihoods in Tigray, Northern Ethiopia. - Forest Policy and Economics 11: 109-117.

[6] Belcher, B., Achdiawan, R., Dewi, S. (2015): Forest-based livelihoods strategies conditioned by market remoteness and forest proximity in Jharkhand, India. - World Development 66: 269-279.

[7] BirdLife International. (2014): Important bird areas factsheet: Mount Rata and Rumpi Hills Forest Reserve. - http://www.birdlife.org/datazone/sitefactsheet.php?id= 6127. Retrieved $06^{\text {th }}$ October 2017.

[8] BUCREP (2015): Central Bureau of the Census and Population Studies of Cameroon. Population and Housing Census Report. - National Institute of Statistics Yaoundé, Central Region, Republic of Cameroon.

[9] Bwalya, S. (2013): Household dependence on forest income in rural Zambia. - Zambia Social Science Journal 2: 67-86.

[10] Chia, E., Somorin, A., Sonwa, D., Tiani, A. (2013): Local vulnerability, forest communities and forest carbon conservation: case of southern Cameroon. - International Journal of Biodiversity and Conservation 5: 498-507.

[11] Dembner, S. A., Perlis, A. (1999): Towards a Harmonized Definition of Non-Wood Forest Products. - Unasylva 198, FAO, Rome.

[12] Ekoungoulou, R., Fousseni, F., Mukete, B., Ifo, S., Loumeto, J., Liu, X., Niu, K. (2018): Assessing the effectiveness of protected areas on floristic diversity in tropical forests. Applied Ecology and Environmental Research 16(1): 837-853.

[13] Etongo, D., Glover, K. (2012): Participatory resource mapping for livelihood values derived from the forest in Ekondo-Titi subregion, Cameroon: A gender analysis. International Journal of Forestry Research 2012: 1-10. 
[14] Etongo, D., Djenontin, I., Kanninen, M., Fobissie, K., Korhonen-Kurki, K., Djoudi, H. (2015): Land tenure, asset heterogeneity and deforestation in southern Burkina Faso. Forest Policy and Economics 61: 51-58.

[15] Ewane, B., Ewane, O., Heon-Ho, L. (2015): Challenges to sustainable forest management and community livelihoods sustenance in Cameroon: evidence from the southern bakundu forest reserve in southwest Cameroon. - Journal of Sustainable Development 8(9): 226-239.

[16] Garekae, H., Tsompie, O., Lepetu, J (2017): Socio-economic factors influencing household forest dependency in Chobe enclave, Botswana. - Ecological Processes 6: 40. DOI: 10.1186/s13717-017-0107-3.

[17] Hajost, S., Zerbock, O. (2013): Lessons Learned from Community Forestry and Their Relevance for REDD+. - USAID-supported Forest Carbon, Markets and Communities Program, Washington, DC, USA.

[18] Jindal, R., Kerr, J., Carter, S. (2012): Livelihood carbon forestry? Impacts of the N'hambita community carbon project in Mozambique. - World Development 40: 21232135.

[19] Kamanga, P., Vedeld, P., Sjaastad, E. (2009): Forest incomes and rural livelihoods in Chiradzulu District, Malawi. - Ecological Economics 68(3): 613-624.

[20] Kimengsi, J., Lambi, C. (2015): Pamol Plantations Plc: prelude to a looming population problem in Ekondo-Titi sub-division, south west region of Cameroon. - Journal of Sustainable Development in Africa 17(3): 79-95.

[21] Kleinbaum, G., Kupper, L., Muller, K. (1998): Applied Regression Analysis and other Multivariate Methods, pp.111-119. - Duxbury Press, Toronto.

[22] Lambi, M., Kimengsi, J., Kometa, C., Tata, E. (2012): The management and challenges of protected areas and the sustenance of local livelihoods in Cameroon. - Environment and Natural Resources Research 2(3): 10-18.

[23] Lang, C. (2015): Parallel Worlds: Illegal Logging and REDD in Cameroon. http://www.redd-monitor.org/2015/01/27/parallel-worlds-illegal-logging-and-redd-incameroon/. Retrieved 7th October 2017.

[24] Levang, P., Lescuyer, G., Dehu, C. (2015): Does gathering really pay? Case studies from forest areas of the East and South regions of Cameroon. - Forest, Trees and Livelihoods 24: $128-143$.

[25] Linder, J (2013): African primate diversity threatened by "new wave" of industrial oil palm expansion. - African Primates 8: 25-38.

[26] Makoudjou, A., Levang, P., Tieguhong, J. (2017): The role of forest resources in income inequality in Cameroon. - Forests, Trees and Livelihoods 2017: 1-16.

[27] Malleson, R. (2000): Forest Livelihoods in Southwest Province, Cameroon: An evaluation of the Korup Experience. - PhD Thesis, University College, London England.

[28] Mamo, G., Sjaastad, E., Vedeld, P. (2007): Economic dependence on forest resources: a case from Dendi District, Ethiopia. - Forest Policy and Economics 9: 916-927.

[29] Mbatu, R. (2006): Forest policy: forest loss and land use cover change in Cameroon. $\mathrm{PhD}$ Thesis, Oklahoma State University, Stillwater United States of America.

[30] McElwee, D. (2008): Forest environmental income in Vietnam: household socioeconomic factors influencing forest use. - Environmental Conservation 35: 147-159.

[31] Mukete, B., Sun, Y., Zama, E., Monono, S. (2016a): Paper consumption and environmental impact in an emerging economy. - Journal of Energy, Environmental \& Chemical Engineering 1(1): 13-18.

[32] Mukete, B., Sun, Y., Zama, E., Achem, B., Mukete, T., Ndolo, L., Lonje, B. (2016b): Environmental degradation in conflict and post-conflict regions. - International Journal of Environmental Protection and Policy 4(6): 187-195.

[33] Mukete, B., Sun, Y., Ayonghe, S., Ojong, L., Itoe, C., Tamungang, R. (2017): Adaptation of women to climate variability in the southern slopes of the Rumpi hills of Cameroon. Agriculture, Forestry and Fisheries 5: 272-279. 
[34] Mukete, B., Sun, Y., Etongo, D., Sajjad, S., Ngoe, M., Tamungang, R. (2018a): Cameroon must focus on SDGs in its economic development plans. - Environment: Science and Policy for Sustainable Development 60(2): 25-32.

[35] Mukete, B., Sun, Y., Etongo, D., Sajjad, S., Abdul, M. (2018b): Assessing the drivers of land use change in the Rumpi hills forest protected area, Cameroon. Journal of Sustainable Forestry. https://doi.org/10.1080/10549811.2018.1449121.

[36] Murphy, R. (1999): Return migrant entrepreneurs and economic diversification in two counties in south Jiangxi, China. - Journal of International Development 11(4): 661-672.

[37] Narain, U., Gupta, S., Van, T., Veld, K. (2008): Poverty and resource dependence in rural India. - Ecological Economics 66: 161-176.

[38] Nguyen, T., Truong, L., Bühler, D., Grote, U. (2015): Rural livelihoods and environmental resource dependence in Cambodia. - Ecological Economics 120: 282-295. https://doi.org/10.1016/j.ecolecon.2015.11.001.

[39] Ofoegbu, C., Chirwa, P., Francis, J., Babalola, D. (2017): Socio-economic factors influencing household dependence on forests and its implication for forest-based climate change interventions. - Southern Forests: A Journal of Forest Science 79(2): 109-116.

[40] Ofundem, T., Nkongho, R., Awono, A., Levang, P (2017): Bush mango (Irvingia spp.): forest and on-farm resource availability and market chains in the Southwest Region of Cameroon. - Forests, Trees and Livelihoods 26(3): 170-182.

[41] Parker, C., Mitchell, A., Trivedi, M., Mardas, N., Sosis, K (2009): The Little REDD+ Book. - Global Canopy Programme, Oxford.

[42] Peskett, L., Huberman, D, Bowen-Jones, E., Edwards, G., Brown, J (2008): Making REDD work for the poor. A poverty environment partnership (pep) report. Overseas Development Institute (ODI), London UK. http://www.odi.org.uk/sites/odi.org.uk/files/odi-assets/publications-opinionfiles/3451.pdf. Retrieved $4^{\text {th }}$ April 2018.

[43] Phimmachanh, S., Zhang, Y., Mukete, B. (2015): Bamboo resources utilization: a potential source of income to support rural livelihoods. - Applied Ecology and Environmental Sciences 3: 176-183.

[44] Robiglio, V., Ngendakumana, S., Gockowski, J., Yemefack, M., Tchienkoua, M., Mbile, P., Bolognesi, M. (2010): Reducing emissions from all land uses in Cameroon, final national report. - ASB partnership for the tropical forest margins Nairobi, Kenya, 2010. http://www.asb.cgiar.org/PDFwebdocs/CAMEROON_REALU.pdf. Retrieved $11^{\text {th }}$ September, 2017.

[45] SWPA, Southwest Provincial Archives (2016): The Rumpi Hills Native Administration Forest Reserve. - Archives No Qh/c/1938/1, File No 16756 at Southwest Provincial Archives, Buea, Cameroon.

[46] Tieguhong, J., Grouwels, S., Ndoye, O. (2012): Financial status of small and medium scale enterprises based on non-wood forest products (NWFP) in Central Africa. - Forest Policy and Economics 20: 112-119.

[47] Timko, J., Waeber, P., Kozak, R. (2010): The socio-economic contribution of non-timber forest products to rural livelihoods in Sub-Saharan Africa: knowledge gaps and new directions. - International Forestry Review 12(3): 284-294.

[48] Yerima, K., van Ranst, E. (2005): Major Soil Classification Systems Used in the Tropics: Soils of Cameroon. - Trafford Publishing, Canada.

[49] Zenteno, M., Zuidema, P., de Jong, W., Boot, R. (2013): Livelihood strategies and forest dependence: New insights from Bolivian forest communities. - Forest Policy and Economics 26: 12-21. 


\section{APPENDIX}

\section{Drivers of household forest resources dependence}

The econometric model is expressed as follows:

$$
Y=\beta_{0}+\beta_{1} X_{1}+\beta_{2} X_{2}+\beta_{3} X_{3}+?+\beta_{n} X_{n}+E
$$

where $\mathrm{Y}$ is the dependent variable and represents household forest dependence. The eight variables examined in this study and used as dependent variables are included in Table 1.

$\mathrm{Xn}$ are the independent variables and represent the potential causes or human forces that influence the variability of dependent variables. These are the household characteristics that affect forest dependence or 20 explanatory variables.

$\beta o$ is a constant or intercept and it represents the change in the dependent variable when there is no change in the independent variables.

$\beta \mathrm{n}$ are the regression coefficients and represent the percentage change in the dependent variable when the independent variables increase by 1 percent.

$\mathrm{E}$ is the error term or error component and represents the variations of the dependent variable that are not explained by the independent variables included in the model.

1. For Little or no financial cost to use forests: cost variable . regress cost R_610 Married

Source $\mid$ SS df MS Number of obs $=4$

---------+--------------------- F $(2,1)=179.00$

Model | 205.386304 2102.693152 Prob > F = 0.0528

Residual $\mid .5736956581 .573695658$ R-squared $=0.9972$

Total | 205.96368 .6533333 Root MSE = .75743

cost $\mid$ Coef. Std. Err. t P $>|t|$ [95\% Conf. Interval]

R_610 | 3.019815.1617292 18.670.034 .9648504 5.07478

Married | -.927085 .1084228 -8.55 0.074 -2.304727.450557

_cons | 102.017 6.346992 16.070.040 21.3708 182.6632

$$
\text { Cost }=102+3 * R \_610-0.9 * \text { Married }
$$

2. For Forest resource abundance: abundance variable . regress abundance Age_60 Primary

Source $\mid$ SS df MS Number of obs $=4$

----------+----------------------- F $(2,1)=3246.42$

Model | 710.6605472355 .330274 Prob $>\mathrm{F}=0.0124$

Residual | .109452874 1.109452874 R-squared $=0.9998$

Adj R-squared $=0.9995$ 
Total | 710.773236 .923333 Root MSE $=.33084$

abundance | Coef. Std. Err. t P>|t| [95\% Conf. Interval]

Age_60 |-2.114391.0651459-32.46 $0.020-2.942148-1.286633$

Primary | - $1.00905 .0191059-52.810 .012-1.251813-.7662861$

_cons | 139.4373.9911498140.680.005126.8436152.0311

$$
\text { Forest abundance }=139.4-2.1 * A_{g e_{60}}-1 * \text { Primary }
$$

3. For Easy access to forest: access variable (Note: Need to create a categorical variable named Gender to represents male and female household heads)

. regress access M_heads Uneducated

Source $\mid$ SS df MS Number of obs $=4$ $\mathrm{F}(2,1)=$.

Model | 900.249944 2450.124972 Prob > F = 0.0002

Residual $\mid .0000555281 .000055528$ R-squared $=1.0000$

Adj R-squared $=1.0000$

Total | 900.253300 .083333 Root MSE = .00745

access $\mid$ Coef. Std. Err. t P>|t| [95\% Conf. Interval]

M_heads | - $1.929889 .0006424-3004.080 .000-1.938052-1.921726$

Uneducated | 1.359561 .00038093569 .320 .0001 .3547211 .364401

_cons | 135.3894.0345478 3918.900 .000134 .9504135 .8284

$$
\text { access }=135.3-1.9 * M_{-} \text {heads }+1.3 * \text { Uneducated }
$$

. regress access F_heads Uneducated

Source $\mid$ SS df MS Number of obs $=4$ $F(2,1)=$.

Model | 900.249944 2450.124972 Prob > F = 0.0002

Residual $\mid .0000555281 .000055528$ R-squared $=1.0000$

Adj R-squared $=1.0000$

Total | 900.253300 .083333 Root MSE = .00745

access | Coef. Std. Err. t P>|t| [95\% Conf. Interval]

F_heads | 1.929889 .00064243004 .080 .0001 .9217261 .938052

Uneducated | 1.359561 .00038093569 .320 .0001 .3547211 .364401

_cons | -57.59947.0360972-1595.68 0.000 -58.05813 -57.14081 


$$
\text { Access }=-57.5+1.9 * F_{-} \text {heads }+1.3 * \text { Uneducated }
$$

4. For Absence of alternative energy: alternative variable .regress alternative Age_60 R_1115

Source $\mid$ SS df MS Number of obs $=4$ -

Model | 1070.10193 2535.050966 Prob > F = 0.0023

Residual | .0055687631 .005568763 R-squared $=1.0000$

Total | 1070.1075 3356.7025 Root MSE = .07462 Adj R-squared $=1.0000$

alternative | Coef. Std. Err. t $\mathrm{P}>|\mathrm{t}|$ [95\% Conf. Interval]

Age_60 | -6.2726.0146781 -427.35 $0.001-6.459103-6.086098$

R_1115 |.5818325.006237293.28 0.007.5025817.6610832 _cons | 160.6146.215213746.310.001 157.88 163.3491

$$
\text { Alternative }=160.6-6.2 * \text { Age_60 }+0.5 * R \_115
$$

5. For Unemployment: unemployment variable . regress unemployment R_610 Uneducated

Source $\mid$ SS df MS Number of obs $=4$ -

Model | 779.451562 389.72578 Prob > F = 0.0107

Residual | 088439771.08843977 R-squared $=0.9999$

Total | 779.54 3259.846667 Root MSE = .29739 Adj R-squared $=0.9997$

unemployment | Coef. Std. Err. t P>|t| [95\% Conf. Interval]

R_610 | 199.2705 2.26503587.98 0.007 170.4905 228.0505

Uneducated | -47.25916 .5320716-88.82 0.007 -54.01977 -40.49855

_cons | -226.2528 3.640868-62.14 0.010 -272.5144-179.9912

$$
\text { Unemployment }=-226.2+199.2 * R_{-} 610-47.2 * \text { Uneducated }
$$

6. For Shock avoidance: shock variable . regress shock Single Divorced

Source $\mid$ SS df MS Number of obs $=4$ $F(2,1)=21448.44$ 
Model | 1526.10442 2763.052212 Prob > F = 0.0048

Residual $\mid .0355761241 .035576124 \mathrm{R}$-squared $=1.0000$

Total | 1526.143508 .713333 Root MSE = .18862

Adj R-squared $=0.9999$

shock $\mid$ Coef. Std. Err. t P $>|\mathrm{t}|$ [95\% Conf. Interval]

Single | -4.301556.0247619-173.72 $0.004-4.616186$-3.986926

Divorced | 12.51899 .0726625172 .290 .00411 .5957213 .44225

_cons | 34.70121.72189648.070.01325.5286643.87377

$$
\text { Shock }=34.7-4.3 * \text { Single }+12.5 * \text { Divorced }
$$

7. For Farming ability: farming variable

. regress farming R_1620 Married

Source $\mid$ SS df MS Number of obs $=4$ $F(2,1)=5840.30$

Model | 92.6520679 246.3260339 Prob > F = 0.0093

Residual | .007932127 1.007932127 R-squared $=0.9999$

Adj R-squared $=0.9997$

Total | 92.66330 .8866667 Root MSE = .08906

farming $\mid$ Coef. Std. Err. t P>|t| [95\% Conf. Interval]

R_1620|1.581469.0146697 107.800.006 1.395072 1.767865

Married | -1.544749.0194568 -79.39 0.008 - 1.79197-1.297527

_cons | 162.1497 1.032367 157.07 0.004149 .0322175 .2671

$$
\text { Farming }=162.1+1.5 * R \_1620-1.5 * \text { Married }
$$

8. For Rearing ability: rearing variable

.regress rearing Age_021 Married

Source $\mid$ SS df MS Number of obs $=4$ $\mathrm{F}(2,1)=$.

Model | 978.3240482 489.162024 Prob > F = 0.0019

Residual $\mid .0034518751 .003451875 \mathrm{R}$-squared $=1.0000$ Adj R-squared $=1.0000$

Total | 978.3275 3326.109167 Root MSE = .05875

rearing | Coef. Std. Err. t P>|t| [95\% Conf. Interval] 
Age_021 | .5027929.0068157 73.77 0.009.4161911.5893946

Married | 4.46013.008616 517.65 0.001 4.350653 4.569607

_cons | -218.2605.5876051-371.44 0.002 -225.7267 -210.7942

Animal rearing $=-218.2+0.5 *$ Age_021 $+4.46 *$ Married 